\title{
Effects of freshwater canal discharge on fish assemblages in a subtropical bay: field and laboratory observations
}

\author{
Joseph E. Serafy*, Kenyon C. Lindeman, Todd E. Hopkins**, Jerald S. Ault \\ University of Miami, Rosenstiel School of Marine and Atmospheric Science, Division of Marine Biology and Fisheries, \\ 4600 Rickenbacker Causeway, Miami, Florida 33149, USA
}

\begin{abstract}
A 14 mo trawl survey was conducted at 8 study sites in Biscayne Bay, Florida, USA, to compare the species composition and structure of juvenile fish assemblages found near the mouths of freshwater flood control canals with those in similar areas with relatively stable salinity regimes. Water temperature, salinity, dissolved oxygen and depth measurements were recorded during fish sampling and bottom vegetation was also quantified. The survey yielded a total of 38134 individuals from 95 taxa. Fish species composition was similar among sites, but more species were collected from stableversus variable-salinity areas. Mean fish abundance and the mean abundances of Eucinostomus gula, Lagodon rhomboides, Opsanus beta and Lutjanus griseus shared a general pattern of increase from north to soluth, with highest values occurring at one or more of the canal-influenced sites. In contrast, mean specles richness and the mean abundances of Lucanıa parva, Haemulon sciurus, H. plumleri, and $H$. parra were significantly greater at stable-salinity sites than at variable-salinity sites. Freshwater challenge experiments were then conducted on each of the fishes above, as well as on 2 relatively uncommon species, Cynoscion nebulosus and Cyprinodon variegatus. The mortality of groups exposed to a single, rapid, freshwater pulse (i.e. salinity was changed from approximately $32 \mathrm{ppt}$ to 0 to $32 \mathrm{ppt}$ over 2 h) was compared with that of controls. Of the 8 fishes that dominated the nearshore habitats of Biscayne Bay, 5 exhibited no mortality and L. rhombordes, L. parva, and H. plumeri exhibited 12.5, 50 and $100 \%$ mortality rates, respectively. Mortality was $100 \%$ for the relatively uncommon $C$. nebulosus and $C$. variegatus. Results suggest that the differential osmoregulatory abilities of the species tested may underlie some, but not all, of the structural differences observed between fish assemblages from stable-salinity habitats versus those adjacent to freshwater canals.
\end{abstract}

KEY WORDS: Salinity tolerance Fish assemblages Canal discharge Coastal bays

\section{INTRODUCTION}

Alteration of freshwater flows into coastal marine waters has changed temperature, salinity, and nutrient regimes, reduced the extent of wetlands, and degraded estuarine and nearshore marine habitats (Reddering 1988, Whitfield \& Bruton 1989, Longley 1994). Profound changes to the South Florida (USA) ecosystem have occurred with the construction of an

\footnotetext{
'E-mail: jserafy@rsmas.miami edu

- Present address: Rookery Bay National Estuarine Research

Reserve, 300 Tower Road, Naples, Florida 34113-8059, USA
}

extensive inland and coastal canal system by the U.S. Army Corps of Engineers which began as early as 1917 (Hoffmeister 1974, Teas 1976). Today, the system constitutes a 1400 mile $(2253 \mathrm{~km})$ network of canals, levees, locks and other flood control structures which modulates freshwater flow from Lake Okeechobee south to the Everglades and adjacent bays. These bays, which serve as nursery habitats for a wide diversity of organisms, have experienced drastic changes in both the amount of freshwater they receive and the fashion in which it is delivered. For example, in southern Biscayne Bay, Florida, canal locks are all that separate this occasionally hypersaline lagoon from the entirely 
freshwater canal systems. When the locks open, the salinity of marine waters downstream often drops $25 \mathrm{ppt}$ within $60 \mathrm{~min}$ before recovering as rapidly (Fatt 1986, Wang \& Coffer-Shabica 1988). While drastic drops in salinity can occur naturally in nearshore habitats, they usually result from infrequent events such as hurricanes or cyclones (Cyrus 1988). In Biscayne Bay, routine canal lock operation leads to large and abrupt salinity changes several times a day and over several months, particularly during the rainy season (i.e. May to October) (Fatt 1986)

Rapid salinity fluctuations can represent a significant stress for a marine organism, depending on its osmoregulatory ability and/or its behavioral response. In fishes, abrupt salinity changes can cause hydromineral imbalance in the blood, which tends to become diluted as salinity drops, and concentrated as it rises - either of which can be lethal (Mazeaud et al. 1977). Rectification of osmotic balance in response to salinity stress requires energy expenditure, often at the cost of growth, reproduction and/or resistance to other stressors, including high temperature (Moore 1972, Schreck 1990). Numerous studies have examined the effects of salinity fluctuation, and/or abrupt salinity changes, on invertebrates (e.g. Crisp \& Costlow 1963, Davenport et al. 1975, Drouin et al. 1985, Kumlu \& Jones 1995) and, to a lesser extent, temperate fishes (e.g. Davenport \& Vahl 1979, McGreer et al. 1991, Provencher et al. 1993, De Vries et al. 1995). The impact of low salinity pulses on tropical and subtropical marine invertebrates has received only limited attention (Moore 1972, Albertson 1980, Brook 1982, Montague \& Ley 1993, Irlandi et al. in press). No studies have examined the effects of freshwater pulses on subtropical marine fishes of the Western Atlantic.

In the present study, a trawl survey of nearshore fishes in subtropical Biscayne Bay was supplemented with a series of laboratory-based freshwater challenge experiments. To test the hypothesis of an osmoregulatory basis for fish distribution and abundance in Biscayne Bay, we examined the result of a single freshwater pulse on fishes that were common in field collections and also on species that were relatively uncommon. Our objective was to examine the extent to which a species' osmoregulatory ability, as measured by its post-challenge survival, correlated with its relative abundance at sites with narrow versus wide salinity variation regimes.

\section{MATERIALS AND METHODS}

Field survey. Fishes were sampled monthly from August 1993 to September 1994 from 8 sites identified, from north to sourth as: Biscayne Canal (BC), Little River (LR), Sunset Harbor (SH), Miami River (MR), Rickenbacker Causeway (RC), Matheson Hammock $(\mathrm{MH})$, Black Point (BP), and Turkey Point (TP) (Fig. 1) Abiotic habitat variables measured included surface water temperature, salinity, dissolved oxygen (DO) and depth; these were measured each month during fish sampling. Biotic habitat variables measured were the type and biomass of dominant macrophytes which were quantified from a single sampling effort conducted in June 1994. Vegetation was sampled by harvesting all above-ground vegetation from 3 randomly placed $1 \mathrm{~m}^{2}$ quadrats. In the laboratory, samples were

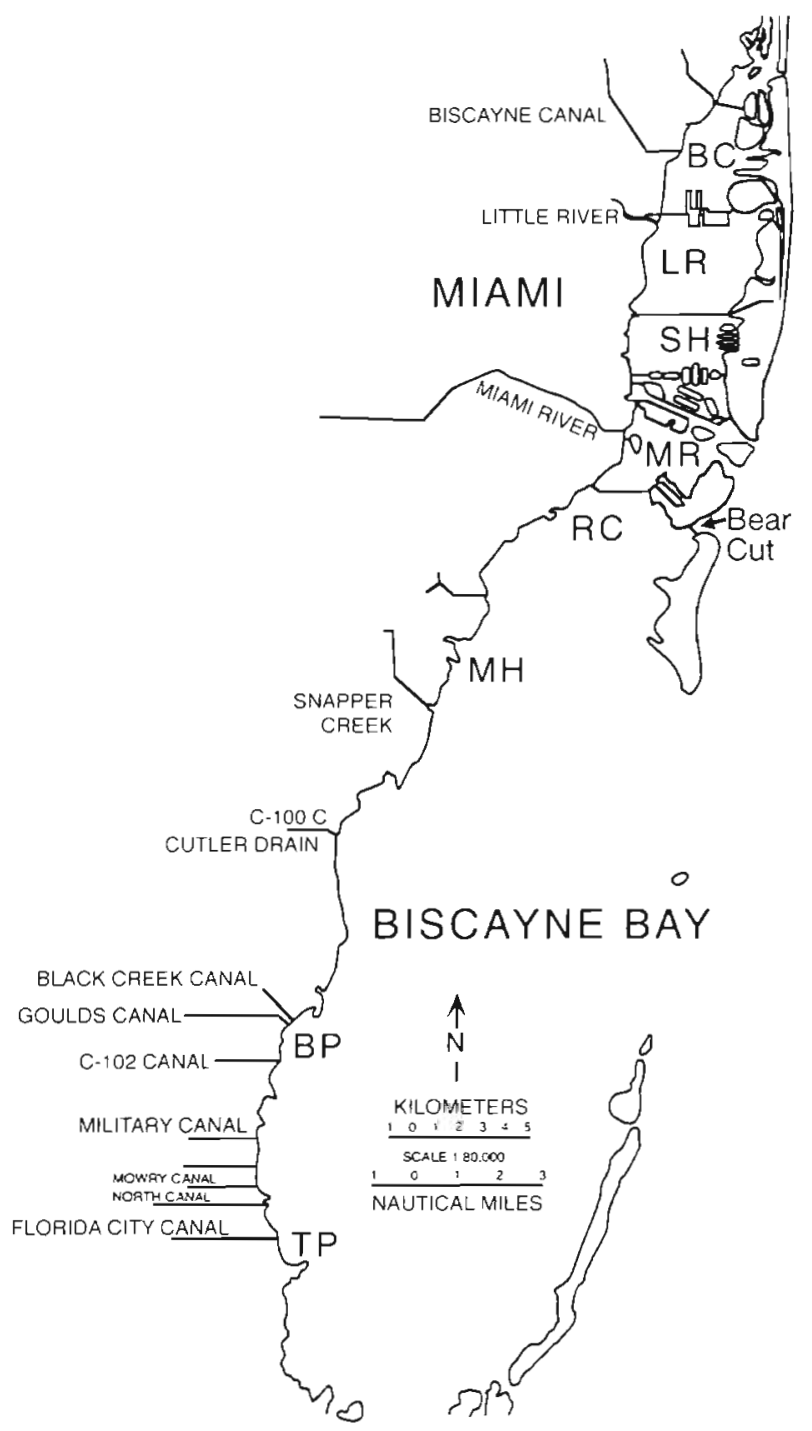

Fig. 1. Location of study sites within Biscayne Bay, Florida, USA. From north to south, sites were designated as Biscayne Canal (BC), Little River (LR), Sunset Harbor (SH), Miami River $(M R)$, Rickenbacker Causeway (RC), Matheson Hammock $(\mathrm{MH})$, Black Point (BP) and Turkey Point (TP) 
separated by species when possible, placed in a drying oven for $72 \mathrm{~h}$ at $50^{\circ} \mathrm{C}$, and then weighed to the nearest gram.

Fish sampling was conducted with 'rollerframe' trawls, the gear used almost exclusively by commercial fishermen to harvest live bait shrimp (Penaeus spp.I from the coastal bays of South Florida. Rollerframe trawls were towed in pairs on either side of a $10.1 \mathrm{~m}$ vessel with a shallow $(0.3 \mathrm{~m})$ draft. Each trawl measured $3 \mathrm{~m}$ wide and $1 \mathrm{~m}$ high; the attached netting was $7 \mathrm{~m}$ long with a mesh size of $10 \mathrm{~mm}$. Trawling was conducted exclusively at night, typically 1 to $2 \mathrm{~h}$ after sunset and 3 to $6 \mathrm{~h}$ before sunrise. Monthly, at each site, two $10 \mathrm{~min}$ tows were conducted at a speed of approximately $2.8 \mathrm{~km} \mathrm{~h}^{-1}$. Trawl catches obtained from each side of the vessel were averaged, thus $\mathrm{n}=2$ for each month at each site. All fishes were identified and measured for total length (TL). To allow an estimate of area sampled, latitude and longitude coordinates were recorded at the beginning and end of each tow using a hand-held global positioning system.

Freshwater challenge experiments. The same experimental set-up that Irlandi et al. (in press) employed in their investigation of freshwater pulses on Biscayne Bay invertebrates was used in this study. Based on the design of Davenport et al. (1975), the set-up consisted of 4 flow-through seawater systems, a 5000 l reservoir of aerated, dechlorinated freshwater, and 2 electric pumps with associated tubing. Each seawater system consisted of an array of five 191 buckets with each array housed within an empty 13411 fiberglass tank with a drain. Fish were placed in the 4 lower buckets of the array, while the fifth bucket served to mix water and regulate flow into those below. Plastic tubing extended from the central mixing bucket to the bottom of each fish-holding bucket, where an air stone was also placed. All 4 flow-through systems were plumbed to receive the mainly oceanic seawater of Bear Cut which varies in salinity from 30 to $35 \mathrm{ppt}$, depending on tide and season. All experiments were conducted during summer when ambient temperature ranged from 28 to $32^{\circ} \mathrm{C}$. Pumps were used to draw freshwater from the reservoir into the mixing buckets of 2 of the systems, thus altering salinity in a subset of the fishholding buckets. Together, therefore, 8 fish containers could be pulsed with freshwater, while 8 provided relatively stable, polyhaline (i.e. control) salinity conditions.

Each challenge experiment involved 16 individuals per species. With the exception of spotted seatrout Cynoscion nebulosus, which were reared from eggs at the University of Miami Experimental Hatchery (UMEH), experimental fish were obtained from sites $\mathrm{SH}, \mathrm{RC}$ or $\mathrm{MH}$ or Bear Cut using either rollerframe

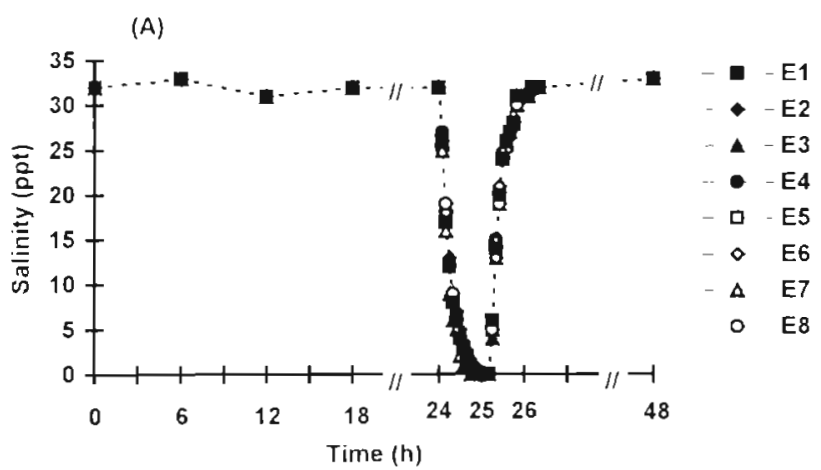

(B)

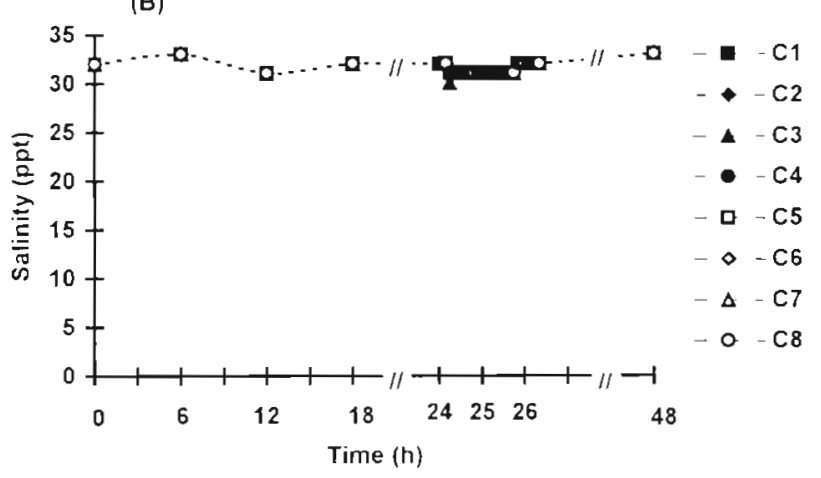

Fig. 2. Example of the standard freshwater challenge (A, challenge; $B$, control) to which fish were subjected in the laboratory. C1-8 and E1-8 indicate salinities in each of the 8 control and 8 freshwater-pulsed (experimental) containers, respectively

trawl, beach seine, or hook-and-line. Prior to experiments, all fish were maintained for $24 \mathrm{~h}$ at the ambient seawater salinities (i.e. 30 to $35 \mathrm{ppt}$ ) flowing into UMEH. Similarly sized individuals that were within the length ranges observed in field collections were used. The experiments began when fish were introduced individually into the lower buckets where they were further acclimated for a 24 h period. Salinity and temperature were measured 3 times during acclimation, every 5 min during a single, 2 h pulse event, and then once again, $24 \mathrm{~h}$ after the pulsing was initiated. Fig. 2 illustrates the pattern of salinity change in each of the 16 fish containers during experiments. Finally, the number of mortalities $24 \mathrm{~h}$ after salinity manipulation was recorded and compared with that of the unpulsed controls.

Data analyses. Statistical analyses were performed using SAS (1990) computer software. Variation in fish species richness, fish abundance (i.e. species combined) and the abundances of selected species were analyzed using analysis of variance (ANOVA) models with site as the independent variable. Numbers of individuals per $1000 \mathrm{~m}^{2}$ were $\log _{\mathrm{e}}$-transformed prior to statistical analyses. Means were compared by using the 
Bonferroni multiple comparison test in which 'experimentwise' error rate was held at the $p<0.1$ level (Sokal \& Rohlf 1987).

Cluster analyses were performed on our field data, with a focus on the abundances of those species for which we also had freshwater tolerance information. Ward's minimum-variance method (Milligan 1980) was used. Normal cluster analysis was performed to examine affinities among sites and seasons given their respective fish assemblages, and inverse cluster analysis was performed to examine affinities among species given their seasonal abundances across sites (Field et al. 1982, Sedberry \& Carter 1993). Both analyses were conducted on a matrix composed of sitespecific mean abundance values $\left(\log _{e^{-}}\right.$ transformed) for each species during the wet season (May to October) and the dry season (November to April) Resulting intercluster distances are presented in dendrograms.

\section{RESULTS}

\section{Field observations}

Sites differed markedly in degree of salinity variation (Fig. $3 \mathrm{~A}$ ), but shared very similar temperature and dissolved oxygen regimes (Fig. 3B, C). Reflecting their respective proximities to freshwater canal mouths, relatively narrow salinity ranges of $<9$ ppt were observed at $\mathrm{SH}, \mathrm{MR}, \mathrm{RC}$ and $\mathrm{MH}$, while relatively wide salinity ranges of 17 to $24 \mathrm{ppt}$ were observed at the remaining sites. Water depths sampled at the study sites ranged from 1.6 to $3.9 \mathrm{~m}$. Mean depth and depth variation were very similar from $\mathrm{RC}$ south to $\mathrm{TP}$, but trends of increase in both were evident from $M R$ north to $\mathrm{BC}$ (Fig. 3D).

Both rooted and unattached bottom vegetation was present at all study sites at biomass levels ranging from 83 to $539 \mathrm{~g}$ dry weight $\mathrm{m}^{-2}$ (Table 1). In terms of rooted macrophytes, Thalassia testudinum dominated at MR, MH and TP, Syringodium filiforme dominated at BC, $\mathrm{LR}$ and $\mathrm{SH}$, and Halodule wrightii dominated at RC and BP. The biomass of unattached macroalgae, which consisted primarily of the red alga Laurencia spp., was especially high at LR and
$\mathrm{MH}$ at the time of vegetation sampling Residence time of the unattached macroalgae at each site was unknown.

Trawling yielded a total 38134 fishes of 95 taxa from 224 samples (Table 2). Total number of taxa recorded at the relatively-stable-salinity sites (i.e. SH, $M R, R C$ and $M H$ ) ranged from 43 to 57 taxa, whereas the remaining sites yielded from 40 to 43 taxa. Six species accounted for $88.5 \%$ of the total catch and from 74.1 to $92.0 \%$ of total catch at each site. In order of decreasing abundance, these were silver jenny
(A)

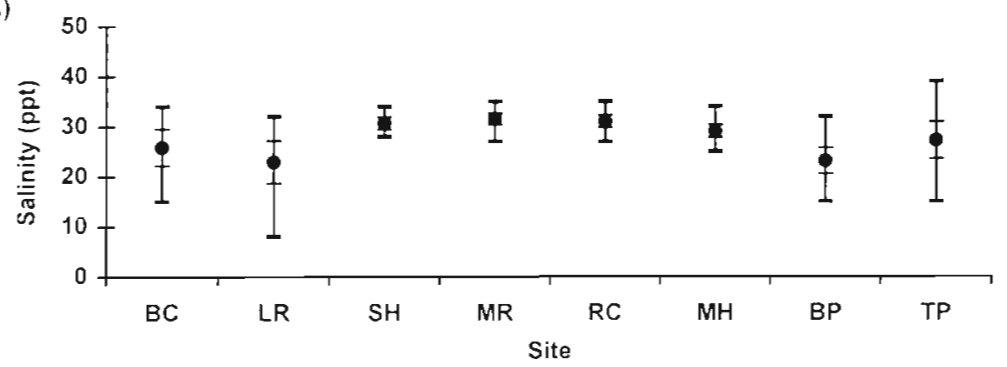

(B)

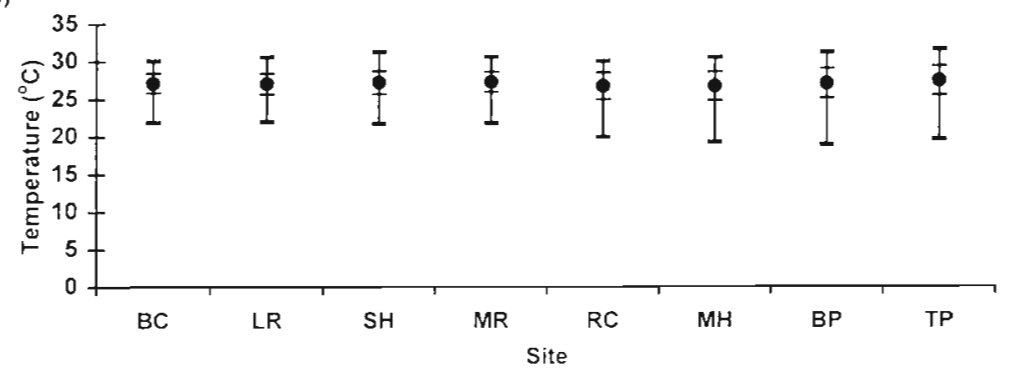

(C)

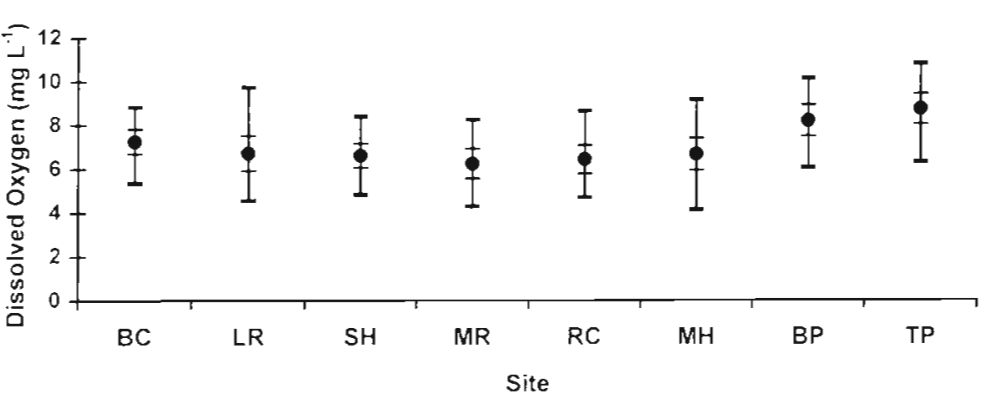

(D)

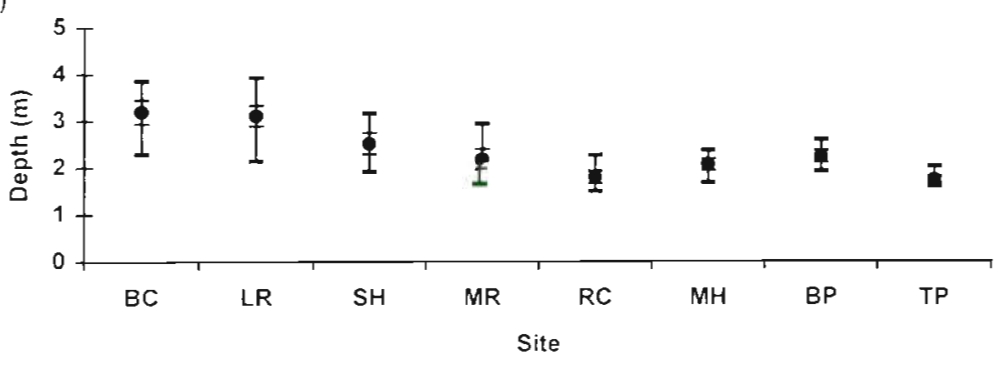

Fig. 3. Plots of (A) salinity, (B) temperature, (C) dissolved oxygen and (D) depth recorded at each site. Mean (solid circles), $\pm 1 \mathrm{SE}$ (inner bars), and range (outer bars) are indicated. Sites are listed north to south along the $x$-axis (see Fig. 1) 
Table 1 . Types and quantities of bottom vegetation at each of the study sites during June 1994. Values are mean biomass ( $g$ dry weight) per $\mathrm{m}^{2}$ See 'Materials and methods: field survey' and Fig. 1 for site names and locations

\begin{tabular}{|rrrrrr|}
\hline \multirow{2}{*}{ Site } & \multicolumn{3}{c}{ Rooted macrophyte } & Unattached & Total \\
& Thalassia & Syringodium & Halodule & macroalga & \\
\hline BC & 0.0 & 10.1 & 0.0 & 80.6 & 90.7 \\
LR & 0.0 & 1.1 & 0.6 & 537.0 & 538.7 \\
SH & 0.0 & 142.2 & 2.1 & 142.2 & 286.5 \\
MR & 39.3 & 7.2 & 27.7 & 12.4 & 86.6 \\
RC & 0.2 & 0.2 & 63.3 & 19.4 & 83.1 \\
MH & 107.4 & 44.5 & 11.4 & 289.8 & 453.1 \\
BP & 0.0 & 18.2 & 35.7 & 40.4 & 94.3 \\
TP & 67.4 & 0.4 & 0.4 & 141.7 & 209.9 \\
& & & & & \\
\hline
\end{tabular}

restricted to $\mathrm{SH}$, the site with the least salinity variation (Fig. $5 \mathrm{~F}$ ).

\section{Laboratory observations}

Laboratory-based salinity challenge experiments were conducted on selected size classes of each of the 10 species above (Table 3). While all fishes held under control conditions were found to survive, exposure to a single freshwater pulse elicited different mortality responses depending on the species. Silver jenny, bluestriped grunt, gulf toadfish, gray snapper and sailors choice

Eucinostomus gula, pinfish Lagodon rhomboides, bluestriped grunt Haemulon sciurus, gulf toadfish Opsanus beta, rainwater killifish Lucania parva and white grunt $H$. plumieri. Gray snapper Lutjanus griseus and sailors choice $H$. parra ranked eighth and eleventh in overall abundance, respectively. Present in the collections, but together constituting only $0.2 \%$ of the total catch, were spotted seatrout Cynoscion nebulosus and sheepshead minnow Cyprinodon variegatus.

Correlations between bottom vegetation biomass and fish species richness and abundance were statislically insignificant. Analysis of variance and subsequent multiple comparison tests revealed significant differences among sites in terms of both mean fish abundance (i.e. species combined) and mean species richness (Figs. 4 \& 5). Upon examination of site-specific means, fish abundance followed the general pattern of increase from northern to southern sites (Fig. 4A). In contrast, site-specific species richness means followed a parabolic pattern from north to south (Fig. 5A): in general, the relatively-stable-salinity, central-bay sites (i.e. SH, MR, RC and MH) yielded significantly higher mean species richness values than the sites with wider salinity variation regimes.

Significant differences were also detected among sites in the respective abundances of 10 species. Silver jenny, pinfish, gulf toadfish and gray snapper each exhibited a mean abundance pattern similar to that observed for overall fish abundance, namely, a general increase from north to south (Fig. 4B to E). On the other hand, bluestriped grunt, rainwater killifish, white grunt, and sailors choice each exhibited parabolic abundance patterns from north to south (Fig. 5B to E) similar to the pattern observed for mean species richness. Spotted seatrout was the only species examined which was most abundant at the northernmost site (BC) and ther declined southwards (Fig. 4F). Catches of sheepshead minnow were very low and entirely appeared to be highly tolerant of the challenge presented; these species exhibited $0 \%$ mortality $24 \mathrm{~h}$ after freshwater pulse exposure. Exposure of pinfish to a freshwater pulse resulted in $12.5 \%$ mortality, while rainwater killifish exhibited $50 \%$ mortality. White grunt, spotted seatrout and sheepshead minnow were completely intolerant of the challenge presented; mortality was $100 \%$ for all 3 species.

\section{Cluster analyses}

Normal and inverse cluster analyses were performed upon the seasonal field abundances of the 10 species for which we had freshwater tolerance information. Normal cluster analysis indicated that the 6 seasonal collections from the 3 southernmost sites (MH, BP and TP; wet and dry seasons) were structurally distinct from those to the north (Fig. 6). However, within the major southern and northern collection clusters, some separation by salinity regime was apparent. For example, within the northern site cluster, all 4 seasonal collections from the variable-salinity sites BC and LR grouped together, distinct from the stable-salinity site collections. The variable-salinity site collections did not separate as cleanly within the southern site cluster, although both TP collections and the BP wet-season collection did group separately from both $\mathrm{MH}$ collections. Inverse cluster analysis, in which species were grouped according to their seasonal distributions across sites, resulted in 2 major clusters (Fig. 7). One cluster contained the 4 most abundant species collected (i.e. silver jenny, pinfish, toadfish and bluestriped grunt) which also proved to be relatively tolerant of our freshwater challenge. The second cluster contained the 4 species that proved relatively intolerant of our freshwater challenge, although it also included the tolerant gray snapper and sailors choice. 


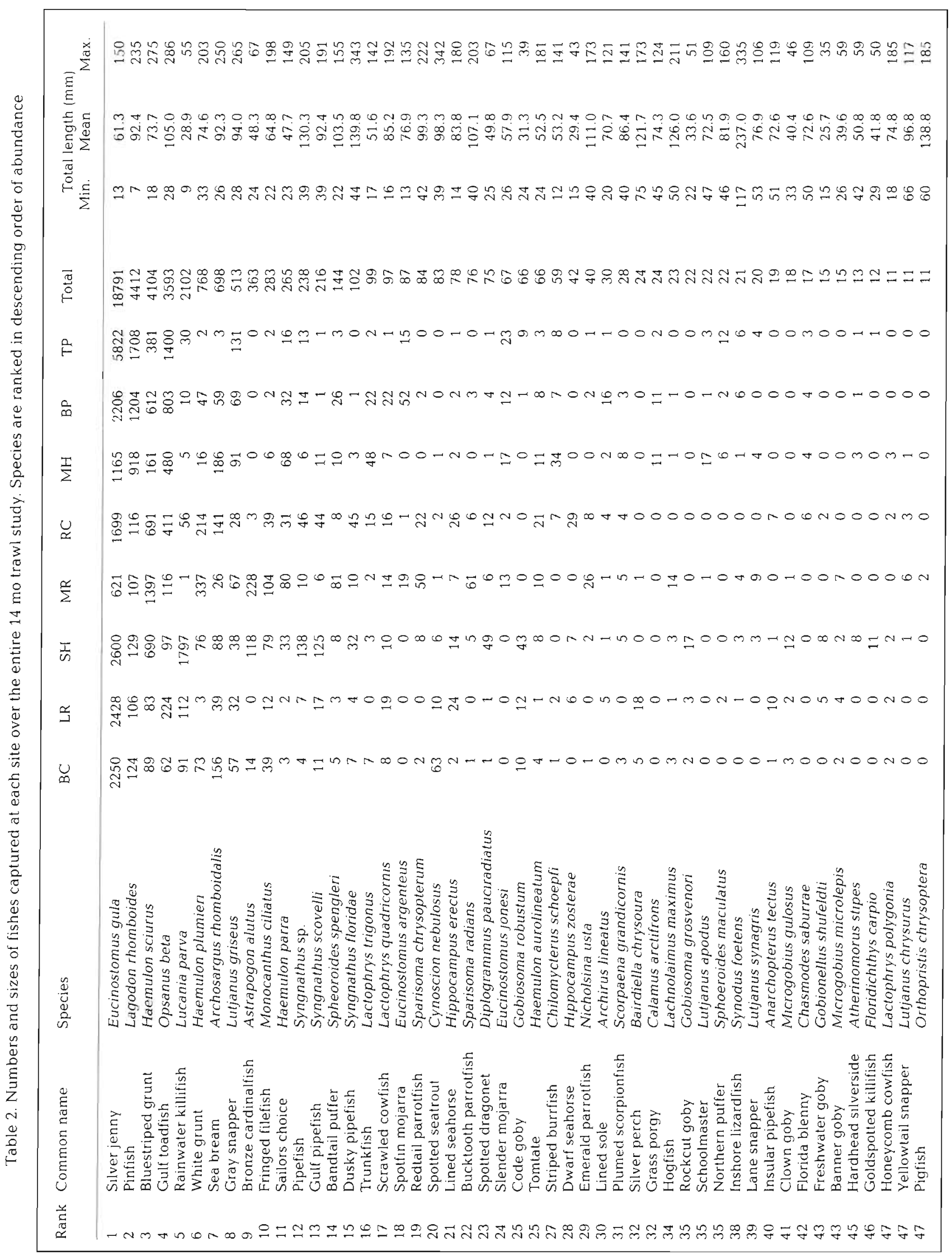




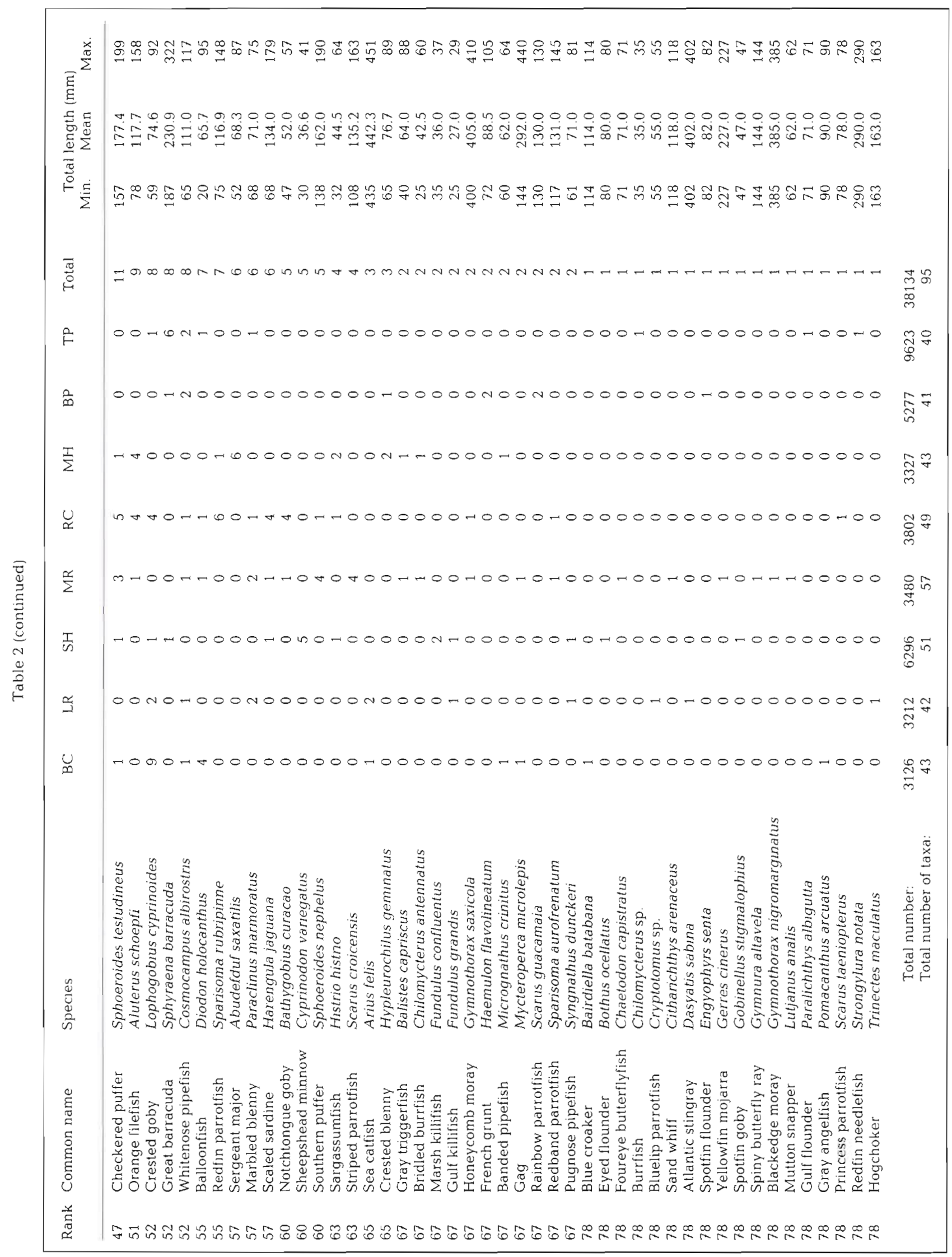


(A)

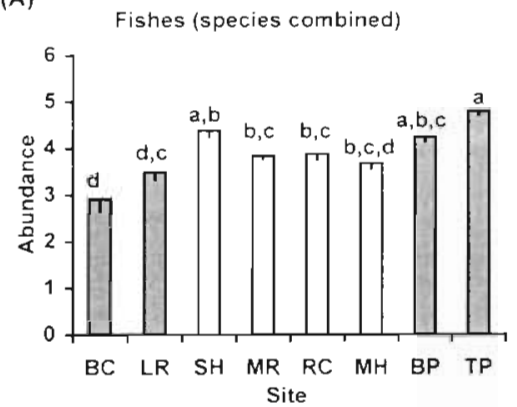

(C)

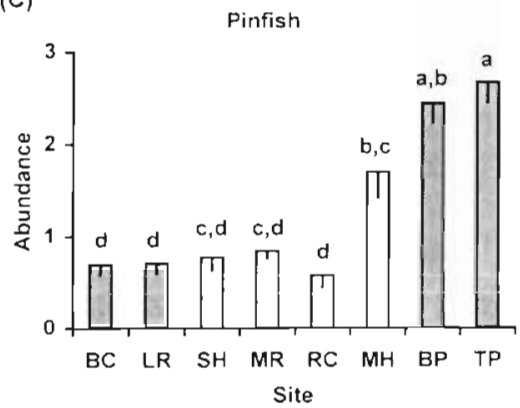

(E)

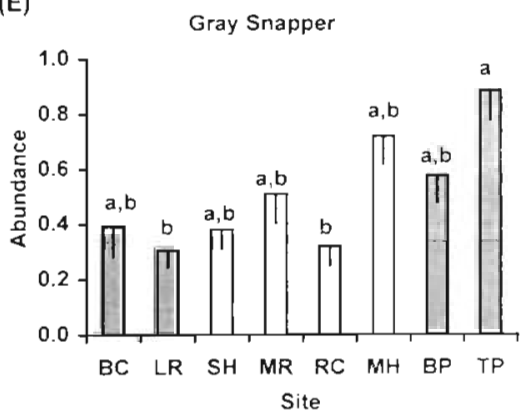

(B)

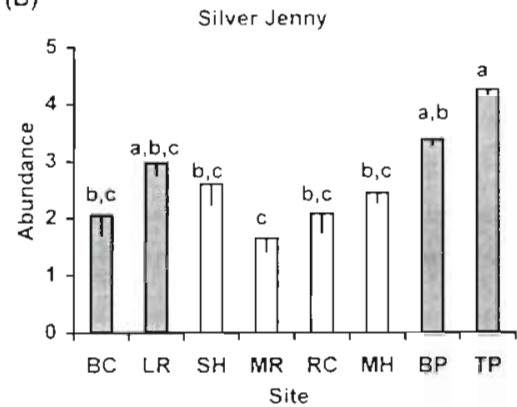

(D)

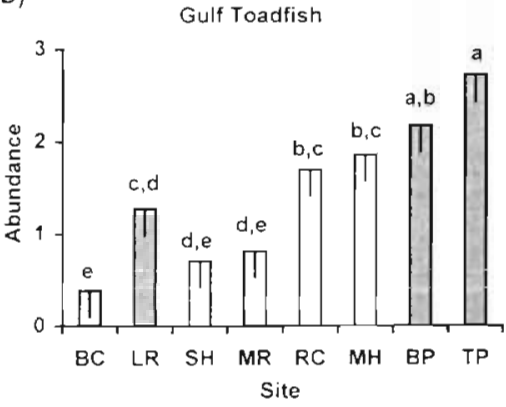

(F)

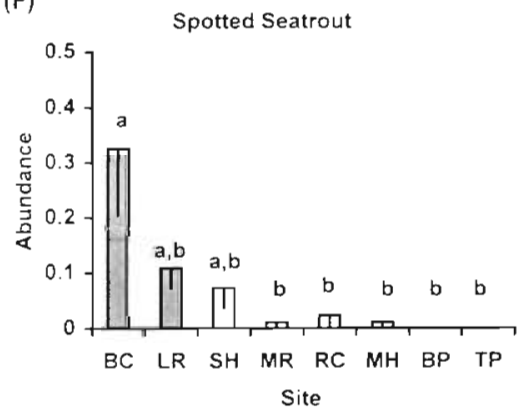

Fig. 4. (A) Mean fish abundance (species combined) at each site and (B-F) mean abundances of species that were highest at one or more of the variable-salinity sites. Sites are arranged from north to south along the $x$-axis. Shaded bars indicate sites with wide salinity regimes $(>17 \mathrm{ppt})$ and open bars indicate those with narrow salinity regimes $(<9 \mathrm{ppt})$. Abundance means are $\log _{\mathrm{e}}$-transformed numbers per $1000 \mathrm{~m}^{2}$. Means $(n=28)$ sharing the same lower case letter are not statistically different. Vertical lines within bars indicate 1 SE

\section{DISCUSSION}

The physiological suitability of habitats ultimately determines the demographic and ecological performance of animals (Huey 1991). Fishes that utilize areas subject to low salinity pulses may (1) remain, if physiologically capable, and expend energy osmoregulating (i.e. energy which might otherwise be used for growth or gamete production) or (2) leave and risk predation and/or food scarcity while searching for more benign habitats. In the present study, we began to investigate the hypothesis that physiological tolerance to dramatic salinity change underlies fish species composition and species-specific abundances at sites with wide-versus narrow-salinity variation. Some of our results were consistent with this hypothesis while others were not.

Field collections revealed that areas subject to wide salinity fluctuations were dominated by many of the same species found in areas with relatively stable salinity regimes. Canal-influenced sites, however, tended to yield (1) fewer fish taxa overall, (2) significantly lower mean species richness values, and (3) significantly fewer rainwater killifish and white grunt. Subsequent laboratory experiments revealed that most (i.e. 6 of 8) fishes that were common to Biscayne Bay's nearshore habitats were tolerant of a single freshwater pulse (i.e. exhibited $<13 \%$ mortality). However, rainwater killifish and white grunt, which overall ranked as the fifth and sixth most abundant fishes, proved to be relatively intolerant of freshwater exposure (i.e. exhibited 50 and $100 \%$ mortality, respectively). Similarly, the relatively uncommon sheepshead minnow, which occurred at only 1 of the 4 stable-salinity sites, also proved to be intolerant of the dramatic salinity change presented in the laboratory. The pattern of sitespecific abundances of rainwater killifish, white grunt and possibly sheepshead minnow, therefore, may reflect their limited abilities to cope with dramatic salinity change relative to other species.

On the other hand, some of our results were only partially consistent or completely inconsistent with the hypothesis of an osmoregulatory basis for fish distribution and abundance in Biscayne Bay. One example was the general pattern of abundance decline from south to north in the 4 species that proved to be relatively tolerant of a freshwater pulse (i.e. silver jenny, pinfish, gulf toadfish and gray snapper). While the abundances of these fishes tended to be highest at the southern sites with wide salinity variation regimes, they were not abundant at the northern sites with wide salinity regimes. This was likely due to the confounding influence of other factors, perhaps bottom vegetation type, depth, or some 
other habitat features not tested here.

Normal cluster analysis on field data also suggested a north-south gradient in assemblage structure existed. However, once geographic location was accounted for, structural differences between assemblages in variable-salinity areas versus stablesalinity areas were evident, especially in northern Biscayne Bay. The inverse cluster analysis was only partially consistent with laboratory results. Although the 4 most abundant, freshwater-tolerant species grouped together separate from all the freshwater-intolerant species, gray snapper and sailors choice grouped with intolerant fishes.

Our laboratory results on juvenile spotted seatrout were inconsistent with our field results. We expected this sciaenid, which uses both estuaries and lagoons as nursery areas, to be tolerant of the freshwater challenge we presented; it clearly was not. A complicating factor may have been that we tested juveniles that had been raised under the stablesalinity, hatchery conditions at UMEH (i.e. 30 to $35 \mathrm{ppt}$ ). We cannot rule out the possibility, therefore, that our test fish were physiologically unrepresentative of wild fish.

Finally, despite their ability to withstand our freshwater challenge, numbers of bluestriped grunt and sailors choice tended to be reduced at all 4 of the canal-influenced sites. Again, these species may have been responding to habitat characteristics unrelated to salinity variation, or possibly to consequences of variable salinity regimes that we did not measure, such as reduced invertebrate prey (Brook 1982, Cyrus 1988) or differences in shelter quality (Montague \& Ley 1993). Because bluestriped grunt and white grunt share more morphological characteristics as early juveniles than any other pair of species within the genus Haemulon (Lindeman 1986), the apparent differences that we found in their respective abundances and osmoregulatory abilities deserve further attention. Martin (1988) suggested differential physical tolerance of salinity and temperature stress was the mechanism for spatial separation of 3 Asiatic glassfishes (genus Ambassis) in estuaries on Africa's
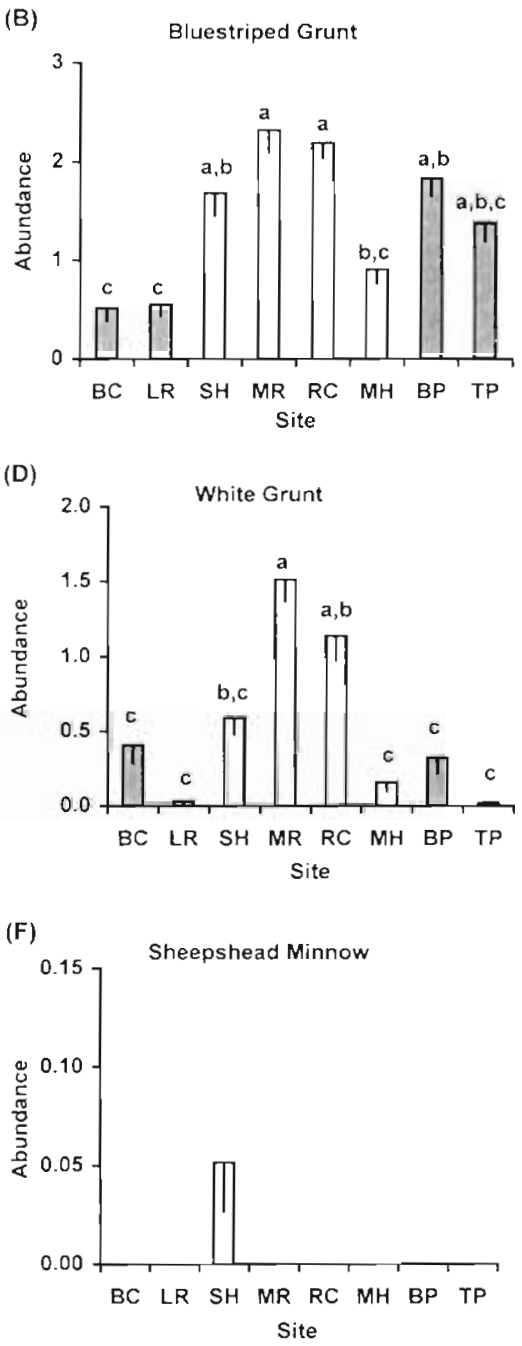

Fig. 5. (A) Mean fish species richness across sites and (B-F) mean abundance patterns of species that were generally highest at the central-bay, stable-salinity sites. with wide salinity regimes ( $>17 \mathrm{ppt}$ ) and open bars indicate those with narrow salinity regimes $(<9 \mathrm{ppt})$. Abundance means are $\log _{\mathrm{e}}$-transformed numbers per $1000 \mathrm{~m}^{2}$. Means $(n=28)$ sharing the same lower case letter are not statistically different. Vertical lines within bars indicate $1 \mathrm{SE}$

southeast coast. Similarly, Sheaves (1996) suggested spatial differences in the abundances of 2 groupers, Epinephelus coioides and E. malabaricus, were reflective of their respective tolerances to hyper- and hyposaline conditions in estuaries of tropical Australia. If further laboratory and field results corroborate our findings, relative abundances of bluestriped and white grunt, or perhaps some measure of haemulid diversity, may serve as useful indicators of the stress associated with canal discharges in our region.

Obviously, the precise mechanism(s) causing reduced numbers of certain fishes near canals cannot be determined from this study. Our focus on lethal effects rather than behavior, physiology or growth perfor- 
Table 3. Species and sizes tested, experimental conditions and results of treshwater challenge experiments. Percent mortality was determined $24 \mathrm{~h}$ after freshwater pulse exposure ( $\mathrm{n}=8$ indivıduals per treatment $)$

\begin{tabular}{|c|c|c|c|c|c|c|}
\hline Rank & $\begin{array}{l}\text { Common name } \\
\text { (Species) }\end{array}$ & $\begin{array}{l}\text { Length range } \\
\text { (nm TL) }\end{array}$ & Treatment & $\begin{array}{c}\text { Temp range } \\
\left({ }^{\circ} \mathrm{C}\right)\end{array}$ & $\begin{array}{l}\text { Salınity range } \\
\text { (ppt) }\end{array}$ & $\begin{array}{l}\text { Percent } \\
\text { mortality }\end{array}$ \\
\hline \multirow[t]{2}{*}{1} & Silver jenny & $48-83$ & Control & $29-31$ & $34-35$ & 0 \\
\hline & (Eucinostomus gula) & & Challenge & $30-31$ & $0-35$ & 0 \\
\hline \multirow[t]{2}{*}{2} & Pinfish & $49-81$ & Control & $29-31$ & $31-32$ & 0 \\
\hline & (Lagodon rhomboides) & & Challenge & $29-31$ & $0-32$ & 12.5 \\
\hline \multirow[t]{2}{*}{3} & Bluestriped grunt & $44-82$ & Control & $31-32$ & $31-32$ & 0 \\
\hline & (Haemulon sciurus) & & Challenge & $31-32$ & $0-32$ & 0 \\
\hline \multirow[t]{2}{*}{4} & Gulf toadfish & $112-170$ & Control & $30-32$ & $31-32$ & 0 \\
\hline & (Opsanus beta) & & Challenge & $29-32$ & $0-32$ & 0 \\
\hline \multirow[t]{2}{*}{5} & Rainwater killifish & $18-31$ & Control & $28-30$ & $30-31$ & 0 \\
\hline & (Lucania parva) & & Challenge & $28-30$ & $0-31$ & 50 \\
\hline \multirow[t]{2}{*}{6} & White grunt & $50-75$ & Control & $29-31$ & $29-30$ & 0 \\
\hline & (Haemulon plumieri) & & Challenge & $28-31$ & $0-30$ & 100 \\
\hline \multirow[t]{2}{*}{8} & Gray snapper & $73-82$ & Control & $29-31$ & $30-31$ & 0 \\
\hline & (Lutjanus griseus) & & Challenge & $30-31$ & $0-31$ & 0 \\
\hline \multirow[t]{2}{*}{11} & Sailors choice & $54-65$ & Control & $29-32$ & $30-31$ & 0 \\
\hline & (Haemulon parra) & & Challenge & $31-32$ & $0-31$ & 0 \\
\hline \multirow[t]{2}{*}{20} & Spotted seatrout & $39-50$ & Control & $29-31$ & $32-33$ & 0 \\
\hline & (Cynoscion nebulosus) & & Challenge & $29-31$ & $0-33$ & 100 \\
\hline \multirow[t]{2}{*}{60} & Sheepshead minnow & $40-56$ & Control & $28-31$ & $31-32$ & 0 \\
\hline & (Cyprinodon variegatus) & & Challenge & $28-30$ & $0-32$ & 100 \\
\hline
\end{tabular}

mance, provides insight only into relative tolerance among nearshore fishes and has limited predictive value. Nevertheless, this study demonstrates that the potential exists for direct mortalities of certain fishes to result from a single, albeit dramatic, canal discharge event. Whether a fish actively avoids a freshwater pulse

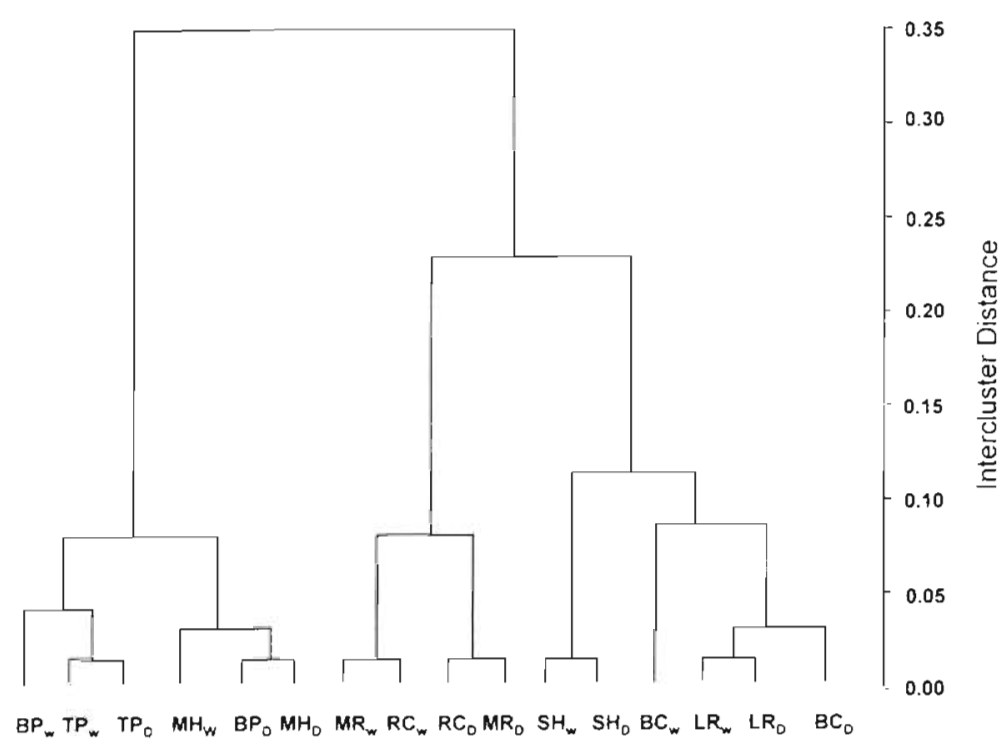

Fig. 6. Results of normal cluster analysis on field data. Dendrogram depicts affinities among sites and seasons (W: wet; $D$ : dry) given the respective abundances of 10 species for which freshwater tolerance was determined (see text for details) or 'waits it out' will depend on size, species, and the perceived risk of predation associated with relocation. Without further research, we cannot assess whether the impact of freshwater pulses on Biscayne Bay's nearshore fishes is mainly direct or indirect, lethal or sublethal. Whatever the case, canal discharges apparently represent levels of disturbance sufficient to reduce the abundance of freshwater-sensitive species and, therefore, fish species diversity.

Comparisons of our field data with previous studies are complicated by differences in sampling gear, precise location of collection, and historical changes in habitat. In general, however, it appears that many of the same fishes have continued to dominate Biscayne Bay's nearshore habitats over the last 20 to 25 yr. For example, Low (1973) reported silver jenny, pinfish, gulf toadfish, white grunt, bluestriped grunt, gray snapper and sailors choice as 'very common' in his central Biscayne Bay seine collections, while he described spotted seatrout as 'common'. Rainwater killifish and sheepshead minnow were not captured by Low (1973).

About 10 yr later, Campos (1985) conducted a monthly survey of Biscayne Bay fishes using rollerframe trawls very similar to those used in the present study. Of the 22 stations that Campos (1985) sampled, 4 


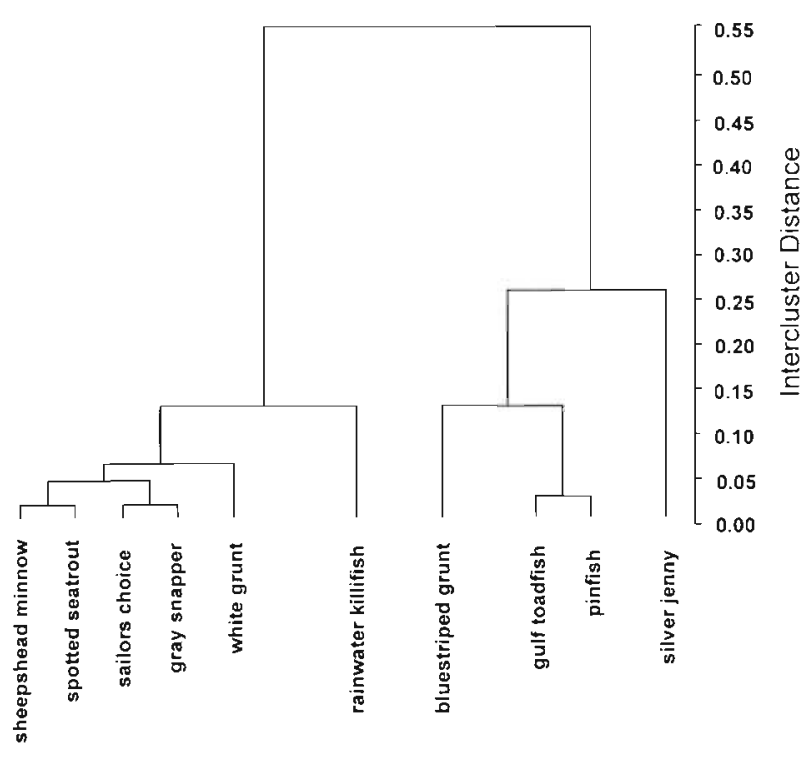

Fig. 7. Results of inverse cluster analysis on field data. Dendrogram depicts affinities among the 10 fishes (for which freshwater tolerance was determined) given their abundances across sites and seasons (see text for details)

were located along the Bay's southwestern shore (i.e. near BP and TP), where salinity was most variable, and 5 were located along the Bay's west-central shore (i.e. near $\mathrm{RC}$ and $\mathrm{MH}$ ), where salinity was relatively stable. As in our study, pinfish, silver jenny, and gulf toadfish predominated at all of Campos' (1985) western shore stations, and differences in their respective abundances at southwestern versus west-central stations were minor. Spatial differences in the abundances of bluestriped grunt, sailors choice and gray snapper, which we found to be tolerant of a freshwater pulse, were negligible in the Campos (1985) study. Consistent with our results, Campos (1985) found that white grunt abundances were on average 5 times greater at the stable-salinity, west-central sites than at the variable-salinity, southwestern sites. Unlike our study, however, Campos (1985) found rainwater killifish was more abundant at southwestern sites, although this species was apparently much rarer in his collections than in ours. Campos (1985) did not capture sheepshead minnow.

Unfortunately, quantitative data on the ichthyofauna of Biscayne Bay prior to canal system construction are not available. The observations of Smith (1896) about $100 \mathrm{yr}$ ago, however, do provide qualitative evidence of a more brackish bay supporting more estuarine species. He reported red drum Sciaenops ocellatus, black drum Pogonias cromis, and eastern oyster Crassostrea virginicus to be abundant in Biscayne Bay. Since at least the $1960 \mathrm{~s}$, these species have appeared to be very rare or completely absent in the bay according to the scientific literature (Roessler 1964, Low 1973, Campos 1985) and personal accounts from local fishermen. We speculate that Biscayne Bay's coastal canal system. combined with the construction of permanent oceanic inlets, has contributed to (1) the virtual elimination of genuinely estuary-dependent species (e.g. red drum), (2) increases in generally stress-tolerant species (e.g. gulf toadfish), and (3) the reduction of juvenile habitat for reef-associated fishes that are vulnerable to rapid drops in salinity (e.g. white grunt)

The ecological consequences of the anthropogenically-driven shift of Biscayne Bay from an estuary to a freshwater-pulsed lagoon are poorly understood. The extent to which abrupt salinity changes result in osmoregulatory failure and death in fishes or compromise their reproduction, development, feeding, growth, and ability to avoid predators requires further study. It is also unclear how coastal organisms will respond to ongoing Everglades habitat restoration efforts which involve changing amounts of freshwater to adjacent bays and eliminating canals, road beds and other obstructions to natural sheet flow (Walters et al. 1992, Harwell et al. 1996). We found that coupling field observations with small-scale laboratory experiments was useful for gaining insight into complex relationships between altered coastal habitats and their fauna. While supplementing field work with laboratory studies has increased the understanding of the effects of extremes in turbidity (e.g. Cyrus \& Blaber 1987a, b) and $\mathrm{pH}$ (Serafy \& Harrell 1993) on temperate estuarine fishes, this combined approach has not been fully applied to the problem of salinity change in subtropical bays. We suggest that future research examine the relative importance of duration, intensity and frequency of freshwater pulses on marine fish assemblages using a combination of field and laboratory investigations.

Acknowledgements. We acknowledge support from NOAA Coastal Ocean Progam (NA37RJ0200/1049), NSF (IBN9118819 and IBN-9507239), the Army Corps of Engineers (DACW39-94-K-0032), and the Florida Department of Environmental Protection (Marine Resources Grant MR018). We are grateful to C. R. Robins for his assistance with species identifications. Invaluable assistance in the field and laboratory was provided by $\mathrm{J}$. Obeid. We also appreciate the efforts of T Capo, T. Curtis, G. Diaz, R. Everhart, W. Freshwater, N. Gassman, J. Krenisky, J. Luznar, R. Orhun, P. Phelan, and C. Schmitz. Finally, we thank M. Harrington, E. Irlandi, A. Myrberg, S. G. Smith and P. Walsh for their manuscript reviews.

\section{LITERATURE CITED}

Albertson HD (1980) Long term effects of high temperature and low salinities on specimens of Melonena corona and Nassarius vibex. PhD dissertation, University of Miami, Coral Gables, FL 
Brook IM (1982) The effect of freshwater canal discharge on the stability of two seagrass benthic communities in Biscayne National Park, Florida. Proc Int Symp Coastal Lagoons, Bordeaux, France. Oceanol Acta 1982:63-72

Campos WL (1985) Distribution patterns of juvenile epibenthic fishes in south Biscayne Bay. Florida. MSc thesis, University of Miami, Coral Gables, FL

Crisp DJ, Costlow JD (1963) The tolerance of developing cirripede embryos to salinity and temperature. Oikos 14: $22-34$

Cyrus DP (1988) Episodic events in estuanes: effects of cyclonic flushing on the benthic fauna and diet of Soled bleekeri (Teleostei) in Lake St Lucia on the south-eastern coast of Africa. J Fish Biol 33(Suppl A):1-7

Cyrus DP, Blaber SJM (1987a) The influence of turbidity on juvenile fishes in estuaries; part 1 . Field studies at Lake St. Lucia on the southeastern coast of Africa. J Exp Mar Biol Ecol 109:53-70

Cyrus DP, Blaber SJM (1987b) The influence of turbidity on juvenile marine fishes in estuaries; part II. Laboratory studies, comparisons with field data and conclusions. J Exp Mar Biol Ecol 109:71-91

Davenport J, Gruffydd LD, Beaumont AR (1975) An apparatus to supply water of fluctuating salinity and its use in a study of the salinity tolerances of larvae of the scallop Pectin maximus L. J Mar Biol Assoc UK 55:391-409

Davenport J, Vahl O (1979) Responses of the fish Blennius pholis to fluctuating salinities. Mar Ecol Prog Ser 1: $101-107$

De Vries MC, Forward RB, Hettler WF (1995) Behavioral response of larval Atlantic menhaden Brevoortia tyrannus (Latrobe) and spot Leiostomus xanthurus (Lacepede) to rates of salinity change. J Exp Mar Biol Ecol 185:93-108

Drouin G, Himmelman JH, Beland P (1985) Impact of tidal salinity fluctuations on echinoderm and mollusc populations. Can J Zool 63:1377-1387

Fatt JC (1986) Canal impact on Biscayne Bay salinities. MSc thesis, University of Miami, Coral Gables, FL

Field JG, Clarke KR, Warwick RM (1982) A practical strategy for analysing multispecies distribution patterns. Mar Ecol Prog Ser 8:37-52

Hoffmeister JE (1974) Land from the sea: the geologic story of South Florida. University of Miami Press, Coral Gables, FL

Harwell MA, Long JF, Bartuska AM, Gentile JH, Harwell CC, Myers V, Ogden JC (1996) Ecosystem management to achieve ecological sustainability: the case of South Florida. Environ Manage 20:497-521

Huey RB (1991) Physiological consequences of habitat selection. Am Nat 137:S91-\$115

Irlandi E, Macia S, Serafy J (in press) Salinity reduction from freshwater canal discharge: effects on mortality and feeding of an urchin (Lytechinus variegatus) and gastropod (Astrea tecta). Bull Mar Sci

Kumlu M, Jones DA (1995) Salinity tolerance of hatcheryreared postlarvae of Penaeus indicus $\mathrm{H}$. Milne Edwards originating from India. Aquaculture 130:287-296

Lindeman KC (1986) Development of larvae of the French grunt, Haemulon flavolineatum, and the comparative development of twelve species of western Atlantic Haemulon (Percoidei, Haemulidae). Bull Mar Sci 39 : $673-716$

Longley WL (1994) Freshwater inflows to Texas bays and estuaries: ecological relationships and methods for determination of needs. Texas Water Development Board and Texas Parks and Wildlife Department, Austin

Low RA (1973) Shoreline grassbed fishes in Biscayne Bay,
Florida, with notes on the availability of clupeid fishes. MSc thesis, University of Miami, Coral Gables, FL

Martin TJ (1988) Interaction of salinity and temperature as a mechanism for spatial separation of three co-existing species of Ambassidae (C uvier) (Teleostel) in estuaries on the south-east coast of Africa. J Fish Biol 33(Suppl A):9-15

Mazeaud MM, Mazeaud MF, Donaldson EM (1977) Primary and secondary effects of stress in fish: some new data and a general review. Trans Am Fish Soc 106:201-222

McGreer JC, Baranyi L. I wuma GK (1991) Physiological responses to challange tests in six stocks of coho salmon (Onchorynchus kisutch). Can J Fish Aquat Sci 48: $1761-1771$

Milligan GW (1980) An examnation of the effect of six types of error perturbation on fifteen clustering algorithms. Psychometrika 45:325-342

Montague CL, Ley JA (1993) A possible effect of salinity fluctuation on abundance of benthic vegetation and associated fauna in Northeastern Florida Bay. Estuaries 16 $707-717$

Moore HB (1972) Aspects of stress in the tropical marine environment. Adv Mar Biol 10:217-269

Provencher L, Munfo J, Dutil JD (1993) Osmotic performance and survival of Atlantic cod (Gadus morhua) at low salinities. Aquaculture 116:219-231

Reddering JSV (1988) Prediction of the effects of reduced river discharge on estuaries of the south-eastern Cape Province, South Africa. S Afr J Sci 84:726-730

Roessler M (1964) A statistical analysis of the variability of fish populations taken by otter trawling in Biscayne Bay, Florida. MSc thesis, University of Miami, Coral Gables, FL

SAS (1990) SAS/STAT user's guide, version 6. SAS Institute, Cary, NC

Schreck CB (1990) Physiological, behavioral and performance indicators of stress. Am Fish Soc Symp 8:29-37

Sedberry GR, Carter J (1.993) The fish community of a shallow tropical lagoon in Belize, Central America. Estuaries 16 : $198-215$

Serafy JE, Harrell RM (1993) Behavioral response of fishes to increasing levels of $\mathrm{pH}$ and dissolved oxygen: field and laboratory observations. Freshwat Biol 30:53-61

Sheaves $M$ (1996) Do spatia] differences in the abundance of two serranid fishes in estuaries of tropical Australia reflect long-term salinity patterns? Mar Ecol Prog Ser 137:39-49

Smith HM (1896) Notes on Biscayne Bay, Florida, with reference to its adaptability as the site of a marine hatching and experimental station. Rep US Commissioner of Fish, Part 21. p 169-186 (Archived at Unıversity of Miamı Marine Library, 4600 Rickenbacker Causeway, Miami, FL 33149. USA)

Sokal RR, Rohlf FJ (1987) Introduction to biostatistics. WH Freeman, New York

Teas HJ, Wanless HR, Chardon R (1976) Effects of man on the shore vegetation of Biscayne Bay. In: Thorhaug $A$ (ed) Biscayne Bay: past/present/future. University of Miami Sea Grant Spec Rep No. 5

Walters C, Gunderson L, Holling CS (1992) Experimental policies for water management in the Everglades. Ecol Appl 2:189-202

Wang JD, Cofer-Shabica SV (1988) The effects of freshwater canal discharges on salinities in Biscayne National Park. Report to the National Park Service, January, 1988 (Available from Biscayne National Park, PO Box 1369, Homestead, FL 33090, USA)

Whitfield AK, Bruton MN (1989) Some biological implications of reduced freshwater inflow into eastern Cape estuaries a preliminary assessment. S Afr J Sci 85:691-694 